\title{
Biotechnology in agriculture
}

\author{
HELAINE CARRER, ANDRÉ LUIZ BARBOSA \\ and DANIEL ALVES RAMIRO
}

\section{Background}

LTHOUGH we think of biotechnology as a new technology, its origin probably dates back more than six thousand years, based on reports that 1 microorganisms were used in fermentation processes for the production of beer and bread. However, according to the fundamentals of agricultural biotechnology, molecular biology and related techniques are the most important events in the history of biotechnology.

Initially, biotechnology was focused on the issue of human and animal health, an area in which microorganisms were used for the production of antibiotics. Reports of in vitro cell cultures date back to the Second World War, when the culture of Penicillium notatum was used for the production of penicillin, whose antibiotic property was discovered by Alexander Fleming in 1929 (Bennett \& Chung, 2001). But it was in the 1970s that methodologies for the use of recombinant DNA and DNA sequencing began to be developed, providing major advances in plant science. The highlights in biotechnology since 1953, when James Watson and Francis Crick described the structure of DNA, to the present day, are described below.

It is striking how biotechnology has revolutionized agriculture with modern technologies that allow us to identify and select genes that encode beneficial traits to be used as molecular markers in assisted selection processes, or to have the expression of a given gene in another organism by transgenesis, and thus more precisely obtain new agronomic and nutritional traits desirable in plants.

\section{Year Historical events in biotechnology}

-1953: Nature scientific journalpublished James Watson's and Francis Crick's manuscript describing the double-helix structure of DNA. The discovery of the structure of DNA resulted in an explosion of research in molecular biology.

- 1956: Heinz Fraenkel-Conrat demonstrated how part of the tobacco mosaic virus can self-assemble and become functional.

- 1957: Francis Crick and George Gamow developed the "central dogma" explaining how DNA functions to produce proteins.

- Matthew Meselson and Frank Stahl demonstrated the replication mechanism of DNA. 
- 1958: The National Seed Storage Laboratory (NSSL) was opened in Fort Collins, Colorado (United States), becoming the first long-term seed storage facility in the world.

- 1965: Scientists reported that genes conveying antibiotic resistance in bacteria are often in extrachromosomal structures called plasmids.

- 1966: Marshall Nirenberg, Heinrich Mathaei and Severo Ochoa demonstrated that a sequence of three nucleotide bases (codon) determines each of 20 amino acids.

- 1970: Howard Temin and David Baltimore, working independently, first isolated reverse transcriptase, an enzyme isolated from certain viruses with the ability to reverse the flow of information from RNA back to DNA. Their work described how viral RNA that infects a host bacterium uses this enzyme to integrate its message into the host's DNA.

- 1972: Paul Berg isolated and employed a restriction enzyme to cut DNA and DNA ligase to join two DNA strands and form a circular hybrid molecule. This was the first recombinant DNA molecule.

- 1973: Stanley Choen, Annie Chang and Herbert Boyer used sectors of viral DNA and bacterial DNA with the same enzymes and produced the first recombinant DNA plasmid with dual antibiotic-resistance genes.

- 1974: Stanley Choen and Herbert Boyer demonstrated the expression of a gene implanted in a bacterium by recombinant DNA methods.

- 1977: Genentech, Inc. reported the production of the first human protein (somatostatin) synthesized in a bacterium.

- Walter Gilbert and Allan Maxam at Harvard University, and Frederick Sanger in England devised a method for sequencing DNA.

- 1978: Genentech, Inc. and the National Medical Center announced laboratory production of human insulin using recombinant DNA technology. David Botstein devised the RFLP technique for polymorphism analysis.

- 1980: Kary Mullis and others developed the PCR (polymerase chain reaction) technique.

- 1982: Genentech, Inc. received approval from the FDA to market genetically engineered human insulin.

- 1983: Patents were granted to companies genetically engineering plants.

- 1985: Genetically modified plants resistant to insects, viruses and bacteria were field tested for the first time.

- 1986: The EPA approved the release of the first genetically modified tobacco plant.

- 1987: Calgene, Inc. received a patent for the tomato polygalacturonase DNA sequence used to produce an antisense RNA sequence that can extend the shelf-life of the fruit.

- 1990: Michael Fromm reported stable transformation of corn using a highspeed gene gun.

An international consortium was established to sequence the human genome.

- 1994: The FDA approved the first genetically modified (GM) food product, the FlavrSavr ${ }^{\circledR}$ tomato. 
- 1995: the Australian Advisory Committee (Gmac) authorized the commercial release of genetically modified blue carnations.

- 1997: Researchers at the Roslin Institute in Scotland cloned Dolly the sheep.

- 1998: Forty million hectares of GM crops were planted globally, predominantly soybean, cotton, canola and corn.

Commercial release of the herbicide-tolerant transgenic soybean was authorized in Brazil and subsequently prohibited by court order.

- 2000: The Arabidopsis thaliana genome is fully sequenced.

A variety of GM rice was created with the vitamin A precursor gene.

- 2001: Complete sequencing of the phytopathogenic bacterium Xylella fastidiosa by a consortium of Brazilian researchers.

The Human Genome Consortium and Celera Group published the human genome.

- 2002: Complete sequencing of the rice genome was carried out by an international consortium.

Dolly the sheep died from respiratory problems.

- 2003: Plants of herbicide-tolerant canola and caterpillar-resistant corn were approved in the United States.

GM herbicide-tolerant corn was approved for use as food in Australia.

In Brazil, the National Biosafety Technical Commission (CTNBio) was created, for the purpose of providing technical and advisory assistance to the federal government in Biosafety Policy related to GM organisms.

Herbicide-tolerant transgenic soybean was released in Brazil.

- 2006: GM rice for human consumption was released in the U.S. Genetically modified grapes were tested in South Africa.

- 2007: Experimental field of transgenic sugarcane with high sugar content by the company Allelyx / Monsanto was approved in Brazil.

Commercial release of insect-resistant and herbicide-tolerant GM corn in Brazil.

- 2008: Australian researchers developed plants with high levels of a fatty acid (UFA) to produce plastics, paints and cosmetics.

Japanese researchers developed the first GM blue rose. Commercial release of GM herbicide-tolerant cotton in Brazil.

- 2009: Commercial release of herbicide-tolerant GM soybean and insect-resistant cotton in Brazil.

Development of the third generation of GM plants with properties such as high salinity and drought tolerance, or for the production of pharmaceutical products such as oral vaccines and specialty products such as biodegradable plastics.

- 2010: Craig Venter created the "synthetic cell" from a laboratory synthesized genome. 


\section{Biotechnology and agriculture}

The establishment of sustainable agriculture that preserves the environment and ensures future food security is a major factor for the development of humanity in the face of climate change and the decline of non-renewable energy reserves. The projected world population growth to nine billion people in 2050 (Ash et al., 2010) poses the challenge of creating advanced and efficient methods to increase food and renewable energy production without, however, depleting natural resources. In 2050 the world will probably be living under the influence of three major announced crises: the decline of oil reserves, the shortage of drinking water and the lack of food for a large part of the population. In this scenario, plant biotechnology plays a central role in finding solutions to mitigate both current and future problems caused by man's lifestyle.

In Brazil, the development of fuel ethanol has proved a viable alternative to reduce oil dependence. However, most of the arable areas on the planet do not have the edaphoclimatic conditions necessary for growing plants with potential for biofuel production. In contrast, the extensive and exclusive cultivation of plants for energy production can cause problems in food supply to the population, such as shortages and rising prices. In this context, biotechnology emerges as a driver to increase productivity, improve production quality and promote the development of energy plants potentially adapted to different environmental conditions. In addition, biotechnology contributes to the development of other sources of bioenergy such as biofuel production from genetically transformed algae (Beer et al., 2009).

Currently, the FAPESP Research Program in Bioenergy (BIOEN) provides financial support for projects that aim to promote the advancement of knowledge and its application in areas related to bioenergy production in Brazil (http://bioenfapesp.org). Among these projects there are studies in progress aimed at conducting the functional analysis of genes involved in sugarcane photosynthesis, sucrose content, cell wall biosynthesis to obtain drought-tolerant and high sugar contentplants among others. The common goal of these projects is the development, in the short term, of technologies that enable efficient renewable energy production.

According to United Nations (UN) estimates, there are over 1.2 billion people in the world without access to safe drinking water, accounting for about 20 percent of the world population (UNESCO, 2007). Agriculture is responsible for about 70 percent of water consumption on the planet (Aquastat-FAO, 2010), and the uncontrolled use of pesticides and fertilizers contributes to the contamination of water aquifers and underground springs. In order to improve the efficiency of water use in agriculture, biotechnology operates on two fronts: the development of drought-tolerant species, thus decreasing intensive irrigation and conserving groundwater, and the genetic improvement of pest- and disease-resistant varieties, thus reducing the need for chemicals in agriculture. 
In food production, biotechnology can provide tools to increase agricultural production by applying molecular knowledge of the function of genes and regulatory networks involved in stress tolerance, growth and development, thus “designing" new plants (Takeda \& Matsuoka, 2008). Genetic transformation of crops enables the functional validation of selected individual genes as well as the direct exploitation of transgenics in plant breeding, aiming plants with desirable agronomic traits.

Currently, the production of transgenic plants is widespread in almost all agricultural regions on the planet, and the use of biotechnology by farmers reaches unprecedented levels as compared to other advanced technologies throughout the history of agriculture. In 2009, genetically modified crops were grown by more than 14 million farmers on 134 million hectares distributed in 25 countries (James, 2010). Brazil ranks second among the countries with the largest area of GM plantations in the world with about 21.4 million hectares, second only to the United States, with 62.5 million hectares (ISAAA, 2010). The reason for this indisputable success lies in the benefits gained from the production of disease- and insect-resistant transgenic plants, in the reduced use of pesticides and in increased production.

According to the FAO (2010), the Brazilian agricultural sector is expected to grow 40 percent by 2019, compared to the base period 2007-2009. In the same period, growth in Russia, China and India will not exceed 26 percent, while more modest increases are expected in the United States and Canada (between 10 percent and 15 percent). The European Union should not exceed 4 percent (OECD-FAO Agricultural Outlook 2010-2019). This sharp growth forecast for Brazilian production is due, on the one hand, to the country's favorable economic and environmental conditions, and on the other to the massive adoption of biotechnology-assisted crops.

In the near future, reduced costs for the development and use of molecular biology products can increase the variety of transgenic plants and their availability to small and medium producers. The inclusion of traits previously absent in the plant can add value to its products, thus multiplying farmers' income and reducing rural exodus. Genetic transformation could be the engine of social change.

In this article we will present a brief summary of the three areas of molecular biology used in plant breeding: genomics, plant genetic transformation and molecular markers.

\section{Plant genomics and gene expression}

Since the establishment of the DNA sequencing methodology by Walter Gilbert and Allan Maxam in 1977, the number of sequences available in genomic databases has grown exponentially, even in recent years with the new generation of high efficiency sequencers such as Roche 454 GS System ${ }^{\circledR}$, Illumina Genome Analyzer ${ }^{\circledR}$ and Life Technologies AB SOLiD ${ }^{\circledR}$ system. 
Currently, over 106 billion nucleotides of 108 million individual sequences are available in the database of the National Center for Biotechnology Information (NCBI), and more than 11 million new sequences were added to that bank last year alone (Benson et al., 2010). This large number of sequences leads us to look forward, with great expectation, to an explosion of knowledge and innovation in various fields of knowledge and especially in health and agriculture.

The complete sequencing of the Arabidopsis thaliana genome was published in 2000 (The Arabidopsis Genome Initiative) and is considered a milestone for plant science. This $120 \mathrm{Mbp}$ genome generally has a copy of each gene and less than 10 percent of repetitive sequences (Mahalakshmi \& Ortiz, 2001), and is considered a small genome compared to other plant species. To date, only two other crops have had their genomes completed: rice (Oryza sativa), with $390 \mathrm{Mbp}$ (Goff et al., 2002, International Rice Genome Sequence Program) in 2002 and corn (Zea mays) with 2,400 Mbp (Wei et al., 2009, Maize Genome Project) in 2009. Nineteen plant species are currently in the completion phase (Table 1) and another 74 are in various sequencing and assembly stages (www. ncbi.nlm.nih.gov/genomes/static/gpstat.html).

Since genomics aims to understand how genes and genetic information are organized within the genome, and also how this organization determines its function, we face the big challenge of seeking the function of genes and understanding these sequences to reduce the genotype-phenotype distance. Therefore, a large number of sequenced genes have unknown function.

To help decipher the gene function, some programs have been established. In 2000, the U.S. National Science Foundation (NSF) launched the Arabidopsis 2010 project with the aim of determining the function of 25,000 genes of this species (Sommerville \& Dangl, 2000). In Brazil there are several initiatives of researchers' consortia in thematic projects such as SUCEST (sugarcane ESTs), Forests (Eucalyptus ESTs) and CitEST (Citrus ESTs). These programs are funded by federal agencies (CNPq, CAPES and FINEP) and state agencies (FAPESP, FAPEMIG and others), along with universities. In the area of bioenergy, individual projects and thematic programs such as BIOEN (http:// bioenfapesp.org) and Bioethanol Biotechnology INCT (www.bioetanol.org.br) have as major goals the functional analysis of sugarcane genes, with emphasis on the bioethanol production. 
Table 1 - Plant genomes in the final sequencing phase and corresponding size when available

\begin{tabular}{l|c}
\hline Genomes completed & Size (Mbp) \\
\hline Amaranthus tuberculatus & 230 \\
\hline Arabidopsis lyrata & $*$ \\
\hline Brachypodium distachyon (brachypodium) & 370 \\
\hline Carica papaya (papaya) & 370 \\
\hline Cucumis sativus (cucumber) & 1200 \\
\hline Glycine max (soybean) & 470 \\
\hline Lotus japonicus (Lotus) & 750 \\
\hline Malus domestica (apple) & $*$ \\
\hline Oryza barthii (rice) & 810 \\
\hline Oryza glaberrima (rice) & $*$ \\
\hline Phoenix dactylifera (date palm) & 510 \\
\hline Physcomitrella patens (moss) & 480 \\
\hline Populus trichocarpa (poplar) & 400 \\
\hline Ricinus communis (castor) & 100 \\
\hline Selaginella moellendorffii & 950 \\
\hline Solanum lycopersicum (tomato) & 760 \\
\hline Sorghum bicolor (sudangrass) & $*$ \\
\hline Vigna radiata (mung bean) & \multirow{2}{*}{\begin{tabular}{c}
$*$ \\
\hline Vitis vinifera (grapevine)
\end{tabular}} \\
\hline & \\
\hline
\end{tabular}

In addition to the DNA information obtained by genome analysis, it is required some knowledge, for example, of which proteins are actually being expressed, when and at what levels of expression, and also any post-transcriptional modifications (Canovas et al. 2004). The fact that the cells of an organism share the same genome but have the most different functions and morphologies, which are the result of different compositions of expressed proteins, illustrates the importance of studying not only the gene sequence but also its expression, so that we can understand its biological functions.

The studies on gene expression, also called transcriptome analysis, is an important methodology for identifying candidate genes, predicting gene function and regulatory regions (Mochida \& Shinozaki, 2010). This method is 
based on hybridization on microarrays and gene chips that enable analyzing the expression of tens of thousands of genes simultaneously. Differentially expressed genes are cloned and functionally analyzed in the cellular metabolism, and genetic transformation is one of the methods used.

\section{Genetic transformation of plants}

Transgenics converges with genetic engineering techniques as a biotechnological solution to problems that affect agriculture in Brazil and worldwide, such as pests, diseases and environmental stresses. Moreover, it can benefit the healthcare, manufacturing and food sectors, thus contributing to add value to agricultural products by bringing together agribusiness and the pharmaceutical and manufacturing industries (Hansen \& Wright, 1999). This technology is a powerful tool to support traditional genetic breeding, which breaks the barriers of crosses between different species and accelerates the plant selection process.

\section{Methods of genetic transformation}

In the 1980s, the somatic hybridization technique based on the complete fusion of two cells from different species enabled the transfer of chromosomes and organelles from one plant to another. Somatic hybridization involves the transfer of polygenic character for obtaining hybrid cells without involving sexual reproduction. However, the technique does not provide detailed information about the inserted genes (Matsumoto, 2001). With advances in recombinant DNA technology, the introduction of exogenous genes into plants has become a reality (Perani et al., 1986). Currently, there are several genes stably introduced into many plant species, conferring resistance to environmental stresses, herbicides, fungi, bacteria, viruses and insects (Lakshmanan et al., 2005). The production of transgenic plants occurs through different methods that can be grouped into two categories: indirect transformation and direct transformation. In the indirect transformation method, gene transfer is mediated by bacteria of the genus Agrobacterium, which are capable of infecting plants naturally and causing a tumor known as crown gall (Chilton et al., 1977; Arisvastava et al., 2009). This bacterium has a plasmid known as Ti, which can be artificially modified to not form the tumor by substitution of the oncogenes to genes of interest which is expressed into the recipient plant's cell. The transformation technique involves putting the plant tissue in contact with the Agrobacterium containing the Ti plasmid with the gene of interest (Hensel et al. 2009). The bacterium then infects the plant tissue, initiating the transfer process and transformation of the plant genome (Brasileiro \& Cançado, 2000). The modified Agrobacterium, which has lost all or part of its transfer DNA (T-DNA), becomes unable to cause tumors in host plants (Pitzschke \& Hirt, 2010). The indirect transformation technique is limited by the low susceptibility of most monocotyledonous and gymnosperms, and of some dicotyledonous to infection with Agrobacterium (Potrikus, 1990). 
The direct transformation methods vary in efficiency and practicality. In these methods, physical and chemical processes are used to produce changes in cell walls and membranes, thus facilitating the introduction of the gene of interest into the genome of the recipient plant. The most efficient methods of genetic transformation are protoplast electroporation, transformation by polyethylene glycol (PEG) and microparticle bombardment or biolistics (Fisk \& Dandekar, 1993), the latter being the most important among all direct methods.

Direct plant transformation using the biolistic technique consists in propelling gold or tungsten microparticles coated with the plasmid containing the gene of interest toward the target tissue. This technique was called biolistics (biological + ballistics) due to the high speed of DNA-coated microprojectiles (Sanford et al., 1991). The microparticles range from 0.6 to $1.5 \mu \mathrm{m}$ in diameter and can be accelerated with compressed air (helium), electric shock wave or gunpowder. In this method, microparticles are launched towards the target tissue to penetrate the cell wall and transfer exogenous DNA into the cells. Biolistics differs from Agrobacterium-induced transformation in that it is more effective in the transformation of plants belonging to different orders, in addition to having greater plasticity in the use of different tissues from the same plant (Brasileiro \& Cançado, 2000).

\section{Production of transgenic crops in the world}

In 2009,14 million farmers in 25 countries were growing genetically modified crops for commercial purposes. Of these, over 90 percent were small farmers in developing countries. Of the total planted, insect-resistant (Bt) and herbicide-tolerant (glyphosate) transgenic varieties accounted for over 99 percent of the crop area (James, 2010).

According to Carpenter (2010), significant differences in production increases between developed and developing countries derive probably from lack of proper pest and weed control in conventional plantations in developing countries. Thus, for farmers in these countries, the use of transgenic crop was much more advantageous than for farmers in developed countries. Brazil was not included in this survey, and data on the use and production of transgenic crops by small farmers are still scarce in the country.

\section{Production of transgenic crops in Brazil}

In 2009, Brazil became the second largest producer of genetically modified (GM) plants in the world, behind only the United States. The area planted with transgenic soybeans, corn and cotton totaled 21.4 million hectares, exceeding by 100,000 hectares the planted area in Argentina (ISAAA, 2010). Of this total, 16.2 million hectares are planted with Roundup Ready soy (glyphosate tolerant), 5 million with $B t$ corn (pest resistant) and 145,000 with transgenic cotton, of which 116, 000 correspond to $B t$ cotton and 29,000 are herbicidetolerant (Figure 1). 


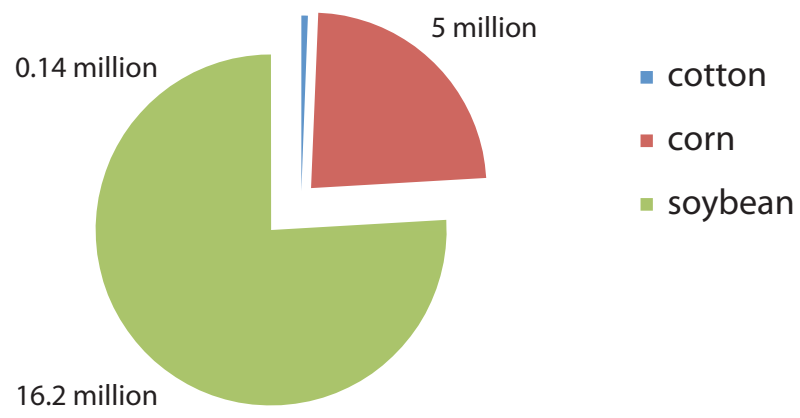

Source ISAAA, 2010

Figure 1 - Area planted with transgenic crops in Brazil (in million hectares).

Despite the predominant production of transgenic soybeans in Brazil, the growth of GM crops in 2009 was led by corn. The production of GM corn was approved by the National Biosafety Technical Committee (CTNBio) in August 2007, and has grown dramatically since then. The production of GM corn in the 2009 harvest increased 400 percent over 2008 (ISAAA, 2010). In the 2010/2011 harvest, 136 transgenic corn cultivars were available to producers, and production is expected to exceed that of the previous harvest (EMBRAPA, 2010).

\section{Molecular markers in plant species}

In recent decades, the development and use of molecular marker techniques has led to significant changes in several areas of biology, especially molecular biology (positional cloning), evolutionary genetics (comparative mapping), quantitative genetics (detection and identification of QTL-controlling loci), and plant breeding (marker assisted selection) (Najimi et al., 2003).

In plant breeding, the development of markers linked to pest- pathogenresistant genes or the use thereof to accelerate the choice of the best parent allows a more precise execution of selection programs when compared to selections based on other markers. In addition, marker-assisted selection allows the construction of genotypes that would hardly be produced through phenotypic selection alone (Alzate-Marin et al., 2005).

A molecular marker is a polymorphic locus that tells us about the genotype of the individual in question. Thus, the markers correspond to the polymorphism present at DNA level. The analysis of this polymorphism using molecular biology is targeted to the genome as a whole, whether or not translated into protein, and is independent of environmental conditions. Contrary to morphological and biochemical markers, molecular markers do not depend on the type of tissue analyzed or on the development stage of the plant. Currently, these markers are used for the most different genetic purposes, ranging from paternity 
tests and identification of kinship to the construction of complex genetic maps (Rocha et al., 2003).

The number of genetic markers is theoretically unlimited, and the genotype of a plant can be determined in an early development stage, as soon as there is sufficient material for DNA extraction. Because of these characteristics, molecular markers are an increasingly useful tool in the breeding of crops of agronomic relevance, especially for traits of difficult phenotypic selection, and are useful for accelerating breeding programs of long lifecycle species, in which a selection cycle can last several years (Maluf et al., 2005).

Numerous molecular marker techniques are currently available (Langridge et al., 2001; Rafalski, 2002). The characteristics of each one, as well as the areas of application, principles and costs thereof are well described (Borém \& Caixeta, 2006). For educational purposes, marker methods can be grouped into two large categories: RFLP markers (restriction fragment length polymorphism) and markers based on the polymerase chain reaction (PCR) method.

RFLP is a first markers' generation technique based on the presence of variability in nucleotide sequences of genomic DNA after digestion with restriction enzymes (Botstein et al. 1980). After DNA digestion, a large number of fragments of varying sizes are generated, which are hybridized to a DNA probe for the identification of homologous fragments. Changes in DNA fragment restriction and/or deletion/insertion sites in the region recognized by the probe are responsible for the polymorphism detected.

The main PCR-based markers are the Randomly Amplified Polymorphic DNA (RAPD), the Amplified Fragment Length Polymorphism (AFLP) and microsatellites or Simple Sequence Repeat (SSR) techniques.

The RAPD technique involves the random amplification of DNA fragments (Williams et al. 1990). The use of a single short primer (10bp) allows the amplification of several parts of the genome. When two primers bind at distances ranging between 200 and 2000 bp from each other on opposite DNA strands, the region between them is amplified in the PCR reaction. The polymorphism detected is due to mutations in both the amplified regions and primer binding sites.

AFLP is the joint analysis of the presence of polymorphism in enzyme restriction sites and in the hybridization of non-specific primers (Vos et al., 1995). This technique uses simultaneously restriction enzymes for DNA cleavage and PCR amplification of fragments obtained from the digestion. It is the combination of restriction enzyme/primers that enables the identification of polymorphisms among individuals.

Microsatellite markers or SSR are formed by sequences of 1 to 6 nucleotides repeated in tandem, found dispersed throughout the genome (Jarne \& Lagoda, 1996). The analysis of the variation among individuals is accomplished by PCR amplification using specific primers constructed in the regions flanking the 
microsatellites. It is the pair of primers (sense and antisense) of the microsatellite that makes up the marker. Polymorphism is represented by the variation in the number of repeated elements that make up the microsatellite, which produce changes in fragment length.

Other molecular marker techniques are being developed and used in the genetic study of plant species, but still to a lesser extent when compared with RAPD, AFLP and SSR and their variables. All these techniques are based on application in gels and, in general, are laborious and expensive.

The considerable advances of genome sequencing have allowed the determination of complete DNA sequences of various organisms and the possibility of comparing them. Perhaps the most promising molecular marking technique today are the markers of the Single-Nucleotide Polymorphisms (SNP) type, based on the identification of polymorphism in sequences where there has been deletion / insertion or mutation of just one nucleotide (Rafalski, 2002). SNP markers are more abundant than microsatellites, thus increasing the chance of success in various applications, such as construction of high resolution genetic maps, QTL mapping, genetic diagnosis, analysis of the genetic structure of the population, and phylogeny among others (Choi et al., 2007). SNP identification is more advanced in the human genome, with approximately 30 million SNP identified in the database of the NCBI (National Center for Biotechnology Information - SNP database), but the identification of single-nucleotide polymorphisms in several plant species has been experiencing a significant increase (ibid.).

\section{Conclusions}

The use of biotechnology for food and bioenergy production represents new opportunities, but also many challenges. While strategies for biofuel production should be adopted according to the possibilities and needs of each country, the production of food for the population should be prioritized in order to avoid risks to food security, especially in countries where the basic levels of food supply are still insufficient. In this context, biotechnology can assist in the development of plants and methods with greater fuel production potential, without the need for increasing the planted area.

In the near future, the development of second generation biofuels may increase fuel production per area planted with crops with energy potential. In the case of sugarcane, first-generation biofuels are those produced from the fermentation of sugars present in sugarcane juice for ethanol production. Secondgeneration biofuels, in turn, are those obtained from cellulose present in the bagasse, which is used in the ethanol production. Thus, biotechnology can assist in developing varieties that are rich in cellulose, with a view to achieving greater efficiency in the production of ethanol. This same strategy can be used on other crops such as corn, whose straw can be used in the production of biofuel, while the seeds are intended for human consumption. 
The biggest benefit of plant biotechnology for humanity, however, will be, unquestionably, the production of genetically improved plants, which will support current and future demands for food security, sustainable agriculture and preservation of natural resources.

\section{References}

ALZATE -MARIN, A. L. et al. Seleção assistida por marcadores moleculares visando ao desenvolvimento de plantas resistentes a doenças, com ênfase em feijoeiro e soja. Fitopatologia Brasileira, v.30, n.4, p.333-42, 2005.

AQUASTAT - FAO. 2010. Available at: <http://www.FAO.org/nr/water/aquastat/main/index.stm>.

ASH, C. et al. Feeding the future. science, v.327, p.797, 2010.

BEER, L. L. et al. Engineering algae for biohydrogen and biofuel production. Current Opinion in Biotechnology, v.20, n.3, p.264-71, 2009.

BENNET, J. W; CHUNG, K.-T. Alexander Fleming and the discovery of penicillin. Advances in Applied Microbiology, v.49, p.163-84, 2001.

BENSON, D. A. et al. GenBank. Nucleic Acids Research, v.38, p.d46-d51, 2010.

BORÉM, A.; CAIXETA, T. E. Marcadores moleculares. Viçosa: UFV, 2006.

BOTSTEIN, D. et al. Construction of genetic linkage map in man using restriction fragment length polymorphism. The American Journal of Human Genetics, v.32, p.314$331,1980$.

BRASILEIRO, A. C. M.; CANÇADO, G. M. de a. Plantas transgênicas. Informe agropecuário, Belo Horizonte, v.21, n.204, p.28-35, 2000.

CANOVAS, F. et al. Plant proteome analysis. Proteomics, v.4, p.285-98, 2004.

CARPENTER, J. E. Peer-reviewed surveys indicate positive impact of commercialized GM crops. Nature Biotechnology, v.28, p.319-21, 2010.

CHILTON, M.-D. et al. Stable incorporation of plasmid DNA into higher plant cells: the molecular basis of crown gall tumorigenesis. Cell, v.11, p.263-71, 1977.

CHOI, I. Y. et al. A soybean transcript map: gene distribution, haplotype and singlenucleotide polymorphism analysis. Genetics, v.2007, v.176, p.685-96, 2007.

EMBRAPA. 2010. Available at: <http://www.cnpms.embrapa.br/milho/cultivares/ index.php>.

FAO. 2010. Available at: <http://www.FAO.org>.

FISK, H. J.; DANDEKAR, A. M. The introduction and expression of transgenes in plants. Scientia Horticulture, v.55, p.5-36, 1993.

GOFF, S. A. et al. A draft sequence of the rice genome (Oryza sativa L. ssp. japonica). Science, v.296, p.92-100, 2002.

HANSEN, G.; WRIGHT, M. S. Recent advances in the transformation of plants. Trends in Plant science, v.4, p.226-31, 1999.

HENSEL, G. et al. Agrobacterium-Mediated Gene transfer to Cereal Crop Plants: Cur- 
rent Protocols for Barley, Wheat, Triticale, and Maize. International Journal of Plant Genomics, doi:10.1155/2009/835608, 2009.

ISAAA. 2010. Available at: <http://www.isaaa.org>.

JAMES, C. Global status of Commercialized Biotech/GM Crops. The First Fourteen Years, 1996 to 2009. In: international service for the acquisition of agri-Biotech applications. Ithaca, New York, 2010.

JARNE, P.; LAGODA, P. J. L. Microsatellites, from molecules to populations and back. Trends in ecology and evolution, v.11, p.424-9, 1996.

LAKSHMANAN, P. et al. Invited review: sugarcane biotechnology: the challenges and opportunities. In vitro Cell Developmental Biology Plant, v.41, p.345-63, 2005.

LANGRIDGE, P. et al. Trends in genetic and genome analyses in wheat: a review. Australian Journal of Agricultural Research, n.52, p.1043-77, 2001.

MAHALAKSHMI, V.; ORTIZ, R. Plant genomics and agriculture: From model organisms to crops, the role of data mining for gene discovery. Electronic Journal of Biotechnology, v.4, p.1-10, 2001.

MALUF, M. P. et al. Genetic diversity of cultivated Coffea arabica inbred lines assessed by RAPD, AFLP and SSR marker systems. Acientia Agricola, v.62, p.366-73, July/ Aug. 2005.

MATSUMOTO, K. Híbridos somáticos. Biotecnologia Ciência e Desenvolvimento, n.20, p.26, 2001.

MOCHIDA, K.; SHINOZAKI, K. Genomics and Bioinformatics Resources for Crop Improvement. Plant Cellular Physiology, v.51, p.497-523, 2010.

NAJIMI, B. et al. Applications des marqueurs moléculaires dans l'amélioration du blé tendre pour la résistance aux maladies et aux insectes. Biotechnology, agronomy, society and environment, v.7, n.1, p.17-35, 2003.

OECD-FAO. 2010. Available at: <http://www.agri-outlook.org>.

PERANI, L. et al. Gene transfer Methods of Crop Improvement: introduction of foreign DNA into plants. Physiologia Plantarum, v.68, p.566-70, 1986.

PITZSCHKE, A.; HIRt, H. New insights into an old story: agrobacterium-induced tumour formation in plants by plant transformation. The EMBO Journal, v.29, p.1021$32,2010$.

POTRYKUS, I. Gene transfer to Plants: assessment and perspectives. Physiologia Plantarum, v.79, p.125-34, 1990.

RAFALSKI, J. A. Novel genetic mapping tools in plants: SNPs and LD-based approaches. Plant Science, v.162, n.3, p.329-33, 2002.

ROCHA, R. B. et al. O mapeamento genético no melhoramento de plantas. Revista Biotecnologia Ciência e Desenvolvimento, n.30, p.27-32, Jan./June. 2003.

SANDFORD, J. C. et al. An improved, helium-driven biolistic device. Technique-A Journal of Methods in Cell and Molecular Biology, v.3, p.3-16, 1991.

SRIVASTAVA, T. et al. A reliable protocol for transformation of Catharanthus roseus through agrobacterium tumefaciens. Physiology and Molecular Biology of Plants, v.15, p.93-8, 2009. 
SOMMERVIllE, C.; DANGL, J. Genomics: Plant Biology in 2010. Science, v.290, p.2077-8, 2000.

TAKEDA, S.; MATSUOKA, M. Genetic approaches to crop improvement: responding to environmental and population changes. Nature reviews Genetics, v.9, p.444-57, 2008.

UNESCO. International Symposium on 'New Directions in Urban Water Management, 2007. Available at: <http://typo38.unesco.org/index.php?urban_water_07>.

VOS, P. et al. AFLP: A new technique for DNA fingerprinting. Nucleic Acid Research Journal, v.23, p.4407-14. 1995.

WEI, F. et al. Detailed analysis of a contigouous 22-Mb region of maize genome. Plos Genetics, v.5, n.11, p.el000728, 2009.

WILLIAMS, J. G. K. et al. DNA polymorphisms amplified by arbitrary primers are useful as genetic markers. Nucleic acid research Journal, v.18, p.6531-3, 1990.

ABSTRACT - Population growth, which is expected to reach 9 billion by 2050, in addition to issues of sustainability and global warming, challenge us to increase the supply of food. An alternative approach to help reduce the impact of this scenario involves biotechnology, which in recent decades has brought remarkable technological opportunities in agriculture that resulted in relevant development in obtaining new plant varieties, improved quality of different foods, and now also in bioenergy. The biotechnology techniques involving molecular markers, genomics and genetic transformation are transforming agriculture and will be discussed in this article.

KEYWORDS: Molecular markers, Transgenics, Bioenergy, Genomics, Food production. 
Helaine Carrer is a professor at the Department of Biological Sciences, Laboratory of Agricultural Biotechnology, "Luiz de Queiroz" School of Agriculture, University of São Paulo. @-hecarrer@esalq.usp.br

André Luiz Barbosa is a CnPq fellow under the Program of the National Institute of Science and Technology (INCT) - Bioethanol. @- abarbosa@esalq.usp.br

Daniel Alves Ramiro is a postdoctoral student at FAPESP, “Luiz de Queiroz" School of Agriculture, University of São Paulo. @ - daramiro@esalq.usp.br

Received on 9 Oct. 2010 and accepted on 18 Oct. 2010. 